ROCZNIKI HUMANISTYCZNE

Tom LXIX, zeszyt $12-2021$

DOI: https://doi.org/10.18290/rh216912-7

\title{
GŁÓWNI PRZEDSTAWICIELE BUDOWNICTWA ORGANOWEGO W STANACH ZJEDNOCZONYCH W LATACH 1815-1860
}

\section{WPROWADZENIE}

Pierwsza połowa XIX w. w Stanach Zjednoczonych to czas przemian społecznych, politycznych i gospodarczych. Wprowadzony w 1807 r. zakaz handlu (Embargo Act) oraz wojna 1812 r. przyczyniły się z jednej strony do stagnacji gospodarczej, ale z drugiej były impulsem do rozwoju przemysłu (Jones 117, 120-25). W 1814 r., po zakończonej pokojem w Gandawie wojnie, Stany Zjednoczone w latach 1815-1860 zmieniły się ,szybciej i gruntowniej niż w ciągu poprzednich dwóch stuleci bądź też w jakimkolwiek późniejszym porównywalnym okresie" (133).

Zmiany te dokonywały się na skutek wielu czynników. Jednym z istotnych była rewolucja w komunikacji. Rozwój transportu (drogi, żegluga morska, sieć kanałów wodnych, kolej) napędzał wzrost gospodarczy, a wraz z nim handel zagraniczny, ułatwiając także przemieszczanie się i osadnictwo. Nie można pominąć także amerykańskiego przemysłu, który będąc we wczesnej fazie rozwoju przed wojną secesyjną i często uzależnionym od europejskiej technologii, mógł się wkrótce poszczycić rodzimymi wynalazkami. Z przemysłem łączyło się powstawanie fabryk i mechanizacja produkcji. Nastąpiła ekspansja na Zachód oraz wzrost liczby ludności, szczególnie w miastach. Było to spowodowane dużą liczbą imigrantów z Irlandii, Niemiec, Wielkiej Brytanii a także, choć w mniejszym zakresie, ze Szwajcarii, Holandii i Skandynawii (Jones 134-51).

Ks. dr ANDRZEJ WIDAK - Wyższe Seminarium Duchowne w Rzeszowie; adres do korespondencji: ul. Witolda 11A, 35-302 Rzeszów; e-mail: widakandrzej@gmail.com.

Rev. Dr. ANDRZEJ WIDAK, Higher Theological Seminary in Rzeszów; address for correspondence: ul. Witolda 11A, 35-302 Rzeszów, Poland; e-mail: widakandrzej@gmail.com. 
Wymienione wyżej czynniki miały istotny wpływ na rozwój budownictwa organowego w Stanach Zjednoczonych i można powiedzieć, że dokonujące się przemiany wynikały niejako naturalnie z tych warunków. Wspomniany ruch ludności czy imigracja przyczyniały się do rozwoju miast, a to łączyło się z budową nowych dużych kościołów, co pociągało za sobą budowę nowych instrumentów. Zmieniał się również sposób budowy organów, które początkowo powstawały $w$ tradycyjnych warsztatach organowych, a potem w fabrykach i z zastosowaniem technologii przemysłowych (choć nadal działali organmistrzowie posługujący się starymi metodami $)^{1}$.

Tematyka budownictwa organowego w Stanach Zjednoczonych jest skromnie opisana w polskiej literaturze organologicznej. Należy zaznaczyć, że Instytucie Muzykologii KUL powstały dwie prace magisterskie zajmujące się historią budownictwa organowego w Stanach Zjednoczonych w okresie od XVII do I poł. XIX w. ${ }^{2}$ Oparte zostały głównie na publikacji O. Ochse „The History of the Organ in the United States" wydanej w Indianapolis w $1988 \mathrm{r}$. W pracy Roberta Mazurkiewicza zostało omówione budownictwo organowe w XVII i XVIII w. na tle ówczesnych uwarunkowań polityczno-społecznych (okres początkowej kolonizacji, działalność misyjna, redukcje). Autor opisuje działalność budowniczych organów, a zwłaszcza Johanna G. Klemma i Thomasa Johnstona, uważanych za pierwszych profesjonalnych organmistrzów amerykańskich. Praca Joanny Kuli obejmuje rozwój budownictwa organowego w Stanach Zjednoczonych w latach 1780-1860. Autorka omawia działalność organmistrzów pochodzenia niemieckiego na terenach Pensylwanii z uwzględnieniem Davida Tannenberga, uważanego za jednego z najważniejszych amerykańskich organmistrzów. Opisuje prace organmistrzów działający głównie na terenach Nowej Anglii, Nowego Jorku (William Goodrich, Henry Pratt, Johann Geib, Thomas Hall, Thomas Appleton, Henry Erben), a także $\mathrm{w}$ innych stanach. Warto nadmienić, że $\mathrm{w}$ wymienionych pracach zostały omówione również wydarzenia towarzyszące budowie nowych organów oraz działalność organistów.

W Stanach Zjednoczonych I poł. XIX w. to okres ważnych przemian polityczno-społecznych oraz szybki rozwój przemysłu. Czynniki te miały istotny

${ }^{1}$ Jako przykład można podać jednego z czołowych bostońskich organmistrzów tego czasu W. Goodricha, który w ciągu całej swojej działalności wybudował 49 instrumentów, gdy firma E.\&G.G. Hook wybudowała tyle samo instrumentów w przeciągu zaledwie trzech lat (Ochse 103).

${ }^{2}$ Zob. Joanna Kula. Budownictwo organowe na terenie Stanów Zjednoczonych Ameryki Pólnocnej $w$ latach 1760-1860 (studium historyczne). Mps pracy mgr. KUL, 2001; Robert Mazurkiewicz. Budownictwo organowe na terenie dzisiejszych Stanów Zjednoczonych Ameryki Pólnocnej w wiekach: XVII-XVIII. Studium historyczno-instrumentoznawcze. Mps pracy mgr. KUL, 1998. 
wpływ na budownictwo organowe. $\mathrm{Z}$ tego względu niniejszy artykuł koncentruje się na latach $1815-1860^{3}$ i jest przyczynkiem do historii budownictwa organowego w Stanach Zjednoczonych tego okresu. W omawianym okresie na czoło wybijały się głównie trzy ośrodki, w których koncentruje się budownictwo organowe, a były to: Nowa Anglia, Nowy Jork oraz Pensylwania (Kassel, „United States of America” 583-98). W mniejszym stopniu budownictwo organowe rozwijało się w stanach takich jak: Maryland i Waszyngton, Południowa Karolina, Wirginia, Georgia i Luizjana, Ohio, Missouri i Illinois, Cleveland, St. Louis, Teksas, Kalifornia i Utah (Ochse 179-90).

\section{NOWA ANGLIA}

Głównym ośrodkiem budownictwa organowego były tereny Nowej Anglii ${ }^{4}$ wraz z Bostonem, nazywanym w tym czasie intelektualną stolicą Stanów Zjednoczonych (Ochse 114). W tym okresie działało kilku znacznych budowniczych takich jak: bracia Goodrich, Thomas Appleton, Elias i George Hook, bracia Stevens, William Allen Johnson, William B. D. Simmons czy Henry Pilcher.

\subsection{Bracia Goodrich: William (1777-1833) i Ebenezer (1782-1841)}

Za „ojca” budownictwa organowego w Bostonie jest uważany William Goodrich. Początkowo pracował wraz z Henrym Prattem, a następnie z Benjaminem Crehore'em. W 1804 r. wraz z bratem Ebenezerem Goodrichem rozpoczęli prowadzenie warsztatu organmistrzowskiego w Bostonie. W $1806 \mathrm{r}$. wybudowali pierwsze organy w kościele Świętego Krzyża w Bostonie. W 1807 r. Ebenezer otworzył swój zakład organmistrzowski i budował głównie organy pokojowe, ale także małe instrumenty do kościołów (Fesperman 106-7).

William przez krótki czas pracował w firmie Hayts, Babcock \& Appleton, a po jej upadku w Mackay \& Co (Ochse 116; Owen, „Goodrich” 226-27). Od 1817 r. aż do śmierci prowadził własny zakład organmistrzowski, najpierw w Bostonie, a następnie w East Cambridge. W jego warsztacie uczyli się sztuki organmistrzowskiej Elias i George Hook, George i William Stevens oraz J. H. Ware (Owen, „Goodrich” 227 i „Goodrich William” 531).

\footnotetext{
${ }^{3}$ Autor przyjął podział za M. A. Jonesem, czyli po zakończeniu wojny z 1812 r. do wojny secesyjnej.

${ }^{4}$ Nowa Anglia obejmuje stany: Connecticut, Rhode Island, New Hampshire, Maine, Vermont, Massachusetts (Encyklopedia Stanów Historii Stanów Zjednoczonych Ameryki Pótnocnej 322).
} 
Goodrich wybudował 38 organów przeznaczonych do kościołów oraz 11 organów pokojowych (Ochse 116). Z wybudowanych przez niego organów zachowały się trzy lub cztery instrumenty. Cieszyły się one dobrą opinią ze względu na „staranną intonację i miłe brzmienie”. Goodrich pozostawał pod wpływem traktatu „L'Art du Facteur d'Orgues” Don Bedos de Celles, wprowadził kilka innowacji, między innymi miechy wyrównawcze. Uważany jest za jednego z pierwszych, który rozpoczął rozwijać rdzenny amerykański styl w budownictwie organowym, odcinając się od wzorów angielskich (Kassel, „United States of America” 586; Owen, „Goodrich William” 531).

Godnymi odnotowania są 26-głosowe organy $(3 \mathrm{M} / \mathrm{P})$ wybudowane w latach 1826-1827 w kościele Św. Pawła w Bostonie (Ochse 117):

Great-organ

First Open Diapason $8^{\prime}$ Second Open Diapason 8'

Stopped Diapason 8'

First Principal 4'

Second Principal 4'

Twelfth $2^{2} / 3^{\prime}$

Fifteenth $2^{\prime}$

Tierce $13 / 5^{\prime}$

Cornet V

Sesquialter III

First Trumpet $8^{\prime}$

Second Trumpet 8

Pedal

Open Double-Diapason Bass
Swell

Open Diapason 8' Stopped Diapason $8^{\prime}$ Principal 4'

Cornet III

Trumpet $8^{\prime}$

Hautboy 8'
Choir-organ

Open Diapason 8' Stopped Diapason 81

Dulciana $8^{\prime}$

Principal 4'

Flute 4'

Twelfth $2^{2} / 3^{\prime}$

Fifteenth $2^{\prime}$

\subsection{Thomas Appleton (1785-1872)}

Thomas Appleton zaczął samodzielnie budować organy w roku 1821, po zamknięciu Franklin Musical Warehouse, gdzie pracował wspólnie z Williamem Goodrichem w latach 1810-1820 (Owen, „Appleton Thomas” 509-10). Szybko zdobył uznanie i otrzymał zlecenia na budowę organów w kościołach w Bostonie, takich jak między innymi Bowdoin St. Church (1831 r.) czy dla towarzystwa muzycznego Handel \& Haydn Society w 1832 r. (Owen, „Appleton" 31-32). Przez krótki czas jego wspólnikiem był Thomas D. Warren (Kassel, „Warren” 619). W 1850 r. przeniósł swój zakład do Reading. Appleton budował głównie organy dwu- i trzymanuałowe. Liczba wybudowanych przez niego organów nie jest dokładnie znana. W latach 1822-1833 wybudował lub zawarł 
umowy na 40 instrumentów, budując dla samego Bostonu aż 36 (Ochse 120). Przyjmuje się, że wybudował ponad 100 organów (Owen, „Appleton” 31-32). Jego instrumenty oprócz walorów brzmieniowych charakteryzowały się kunsztownie wykonanymi szafami organowymi, często z drewna mahoniowego (Owen, „Appleton Thomas” 511). 26-głosowe organy (3M/P) wybudowane w 1831 r. w kościele na Bowdoin Street w Bostonie cieszyły się szczególnym uznaniem. Można zauważyć podobieństwo do organów Goodricha. Dyspozycja instrumentu jest następująca (Ochse 121):

\begin{tabular}{|c|c|c|}
\hline Great & Swell & Choir \\
\hline First Open Diapason 8' & Open Diapason 8' & Open Diapason 8' \\
\hline Second Open Diapason 8' & Stopped Diapason 8' & Stopped \\
\hline Diapason $8^{\prime}$ & Dulciana $8^{\prime}$ & Dulciana $8^{\prime}$ \\
\hline First Stopped Diapason 8' & Principal 4' & Principal 4' \\
\hline Second Stopped Diapason (treble) 8' & Cornet III & Flute $4^{\prime}$ \\
\hline Principal 4' & Hautboy $8^{\prime}$ & Cremona $8^{\prime}$ \\
\hline Twelfth $2^{2} / 3^{\prime}$ & Cremona $8^{\prime}$ & \\
\hline Fifteenth $2^{\prime}$ & & \\
\hline Tierce $13 / 5^{\prime}$ & & \\
\hline Sesquialter III & & \\
\hline Trumpet $8^{\prime}$ & & \\
\hline Clarion 4' & & \\
\hline Pedal & & \\
\hline $\begin{array}{l}\text { Double Diapason 16' } \\
\text { Sub-bass } 8^{\prime}\end{array}$ & & \\
\hline
\end{tabular}

\subsection{Bracia Hook: Elias (1805-1881) i George (1807-1880)}

Duży wpływ na budownictwo organowe w Nowej Anglii mieli bracia Elias i George Greenleaf Hook. Założyli warsztat organmistrzowski w 1827 r. w Salem, w stanie Massachusetts, następnie w 1831 r. przenieśli działalność do Bostonu. W roku 1855 do firmy dołączył Frank H. Hastings ${ }^{5}$. Jednym z ważnych osiągnięć firmy w tym czasie była budowa 34-głosowych organów $(3 \mathrm{M} / \mathrm{P})$ dla Tremont Temple w Bostonie w 1845 r. Instrument ten uważano za pierwszy w mieście, na którym można było wykonywać ówczesną europejską

${ }^{5}$ W 1871 r., kiedy Hastings zostaje jej wspólnikiem firma zmienia nazwę na E. \& G.G. Hook \& Hastings. Najbardziej efektowny okres działalności firmy to lata 70. i 80. XIX w., kiedy Hook \& Hastings (taka nazwa funkcjonowała wówczas) produkowała więcej niż jeden instrument w tygodniu. Upadek firmy rozpoczął się po śmierci Hastingsa (1916), ostatecznie firma zakończyła działalność w 1936 r. (Owen, „Hook \& Hastings” 664-65). 
muzykę organową. W 1852 r. organy te zostały zniszczone i na ich miejsce bracia Hook wybudowali nowe 54-głosowe (4M/P). Do końca 1859 r. firma ukończyła organy oznaczone jako Opus 261. Organy budowane przez firmę Hook zyskały uznanie dzięki wyróżniającej się intonacji, trakturze i głosom językowym (Bishop, „Hook” 258-59; Ochse 124).

Jednym z interesujących instrumentów są 32-głosowe organy (3M/P) z $1854 \mathrm{r}$. wybudowane dla kościoła Unitarian w Jamaica Plain, Massachusetts. Dyspozycja jest następująca (Ochse 124) ${ }^{6}$ :

Great

Grand Open Diapason (T.C) ${ }^{7}$

Open Diapason

Stopped Diapason Bass

Melodia Treble (T.C)

Gamba (T.C)

Principal

Twelfth

Fifteenth

Sesquialtra

Mixture

Trumpet Bass

Trumpet Treble (T.C.)

Clarion

Choir

Dulciana

Viol d'Amour (T.C)

Clarabella ${ }^{10}$

Std. Diapason Bass

Std. Diapason Treble (T.C)

Principal

Flute

Clarionet (to $\mathrm{G}$ )
Swell

$16^{\prime} 44$

$8^{\prime} \quad 56$

$8^{\prime} \quad 12$

$8^{\prime} \quad 44$

$8^{\prime} \quad 44$

4' 56

$2^{2} / 3^{\prime} 56$

$2^{\prime} 56$

III 168

II 112

8' 12

8' 44

4' 56

Bourdon Bass

Bourdon Treble (T.C)

Open Diapason ${ }^{8}$

Viol di Gamba (T.C)

Stopped Diapason Bass

Stopped Diapason Treble (T.C) $\quad 8^{\prime} \quad 12$

Principal

Mixture

Vox Humana

Trumpet

Hautboy (T.E) ${ }^{9}$

Tremulant

Pedal

\begin{tabular}{|c|c|}
\hline $8^{\prime} 56$ & Double Op. Diapason \\
\hline $8^{\prime} 44$ & Bourdon $^{11}$ \\
\hline $8^{\prime} 39$ & D’ble Dulciana \\
\hline $8^{\prime} 12$ & Violoncello \\
\hline $8^{\prime} 44$ & Possaune \\
\hline 4' 56 & \\
\hline 4' 56 & \\
\hline $8^{\prime} 49$ & \\
\hline
\end{tabular}

$\begin{array}{ll}16 & 27\end{array}$

$16^{\prime}-$

$16^{\prime} 27$

$\begin{array}{ll}8^{\prime} & 27\end{array}$

16,27

Uwagi do dyspozycji: Gamba i Vox Humana zostały zainstalowane później. Sekcja choir od $1860 \mathrm{r}$. Zakres pedału początkowo obejmował 17 klawiszy.

\footnotetext{
${ }^{6}$ Obok stopażu została podana liczba piszczałek.

${ }^{7}$ Zapis (T.C) oznacza, że głos rozpoczyna się od ,„”.

${ }^{8} 56$ piszczałek, ale najniższe 7 piszczałek ze Stopped Diapason.

${ }^{9}$ Zapis (T.E) oznacza, że głos rozpoczyna się od „e".

${ }^{10} 44$ piszczałki, ale najniższe 5 ze Stopped Diapason.

11 Transmisja ze Swell.
} 


\subsection{Bracia Stevens: George (1803-1894) i William (1808-1896)}

Wśród budowniczych działających na terenie Nowej Anglii należy wymienić również braci Stevens: George'a i Williama. Obaj pracowali w warsztacie Goodricha. Po jego śmierci w 1833 r. George wraz z Williamem Gayettym założyli firmę, która przetrwała do $1835 \mathrm{r}$. George wybudował ponad 80 organów, jedno- i dwumanuałowych dla małych kościołów (Kassel, „United States of America" 587-88). Młodszy z braci przez pewien czas tworzył spółkę z Horatio Davisem i Jamesem Jewettem. Przez większość swojej działalności budował podobnie jak George organy jedno- i dwumanuałowe dla małych kościołów. Ich instrumenty nie zdobyły takiej popularności, jak organy Appletona czy braci Hook. Nie można odmówić im fachowości, wyrażającej się choćby w doborze głosów budowanych przez nich organów (Ochse 130-32).

\subsection{William Allen Johnson (1816-1901)}

Jednym z kontynuatorów budownictwa organowego w tradycji dynastii Goodrich był William Allen Johnson. Zainteresował się budową organów w 1841 r., kiedy w kościele, w którym pracował, pomagał przy instalacji organów firmy Hook. Początkowo zajął się budową organów salonowych. W $1848 \mathrm{r}$. wybudował 6-głosowe organy dla Grace Church w Chicopee, Massachusetts, następnie w 1849 r. 20-głosowe organy w Westfield dla First Congregational Church (Paterson, „Johnson” 281-82). W 1851 r. otworzył swój warsztat organowy. W 1854 r. wybudował 42-głosowe organy (3M/P) dla South Congregational Church w Hartford. Godnym podkreślenia jest fakt, że brzmienie organów Johnsona z uwagi na „miłą” intonację oraz mocny i jasny ton głosów językowych było wyraźnie rozpoznawalne pośród instrumentów innych amerykańskich firm. Warto dodać, że zapoczątkowana przez niego firma była jedną ze znaczących i działających w drugiej połowie XIX w. (Owen, „Johnson” 684).

\subsection{William B. D. Simmons (1823-1876)}

William B. D. Simmons pierwsze umiejętności organmistrzowskie zdobywał w warsztacie Thomasa Appletona. W latach 1845-1851 współpracował z Thomasem McIntyre'em, zaś od 1856 r. Georgem Fisherem. W swoich organach Simmons zastosował jako jeden $\mathrm{z}$ pierwszych pełny zakres Swell ${ }^{12}$ (Owen, „Simmons” 323). Duży wpływ na budowane przez niego organy miała współpraca z Johnem Willcoxem, czołowym bostońskim organistą. Typowym

\footnotetext{
${ }^{12}$ Niepełny zakres Swell obejmował 37 lub 38 dźwięków.
} 
przykładem tych wpływów są 49-głosowe organy (3M/P) wybudowane dla Appleton Chapel, Harvard University, w 1859 r. (Ochse 139).

\subsection{Joseph Alley (1804-1880), Henry Ward Poole (1826-1890)}

Organy budowano nie tylko dla kościołów, ale również dla prywatnych użytkowników. Nazywane były organami pokojowymi lub salonowymi. Małe organy były także budowane do kościołów. Z czasem budowanie organów salonowych znacznie się zmniejszyło z uwagi na popularność fisharmonii. Wśród budowniczych tego typu organów na szczególną uwagę zasługuje Joseph Alley. Z wybudowanych 37 instrumentów zachował się tylko jeden w First Religious Society w Newburyport (1834). Instrument ten był dwukrotnie przebudowany, ale mimo tego zachował wiele cech z czasu powstania. W latach 1849 i 1851 Alley wraz z Henrym W. Poole'em wybudowali dwa ,enharmoniczne"13 instrumenty, które nie przyniosły oczekiwanego sukcesu. W późniejszym okresie działalności Alley zajmował się robieniem piszczałek dla innych budowniczych (Owen, „Alley” 24-25; Ochse 140-41).

\section{NOWY JORK}

Drugim ważnym ośrodkiem budownictwa organowego w Stanach Zjednoczonych obok Bostonu był Nowy Jork, który w omawianym okresie należał do największych miast (Jones 143) i rozwijało się w nim życie muzyczne. Działały tam towarzystwa muzyczne, takie jak New York Philharmonic Society czy New York Sacred Music Society (Ochse 144). Wśród głównych budowniczych działających w tym czasie należy wymienić: Thomasa Halla, Henry'ego Erbena, Johna Labagha i Richarda Ferrisa oraz George'a Jardine'a.

\subsection{Thomas Hall (1794-1874)}

Urodził się w Anglii w 1794 r. Jego rodzina wyemigrowała do Stanów Zjednoczonych w 1803 r. gdzie Hall podjął praktykę organmistrzowską w warsztacie Johna Lowe'a (Pinel, „Lowe” 311). W 1818 r. przeniósł się do Nowego Jorku i rozpoczął działalność organmistrzowską najpierw samodzielnie a następnie

${ }^{13}$ Organy enharmoniczne miały klawiaturę podzieloną w oktawie na 35 dźwięków, co pozwalało na granie w stroju naturalnym np. średniotonowym. W pierwszym instrumencie Alley i Poole zachowali normalną klawiaturę, zmiana temperacji dokonywała się za pomocą przycisków nożnych. Klawiaturę z 35 dźwiękami w oktawie zastosowali w fisharmonii wybudowanej w 1869 r. (Owen, „Enharmonic Organ” 183). 
z Henrym Erbenem (1824-1827) oraz z Johnem Labaghem (1846-1872). Organy budowane wspólnie z Labaghem należały do instrumentów określanych jako „przeciętne” (Ochse 148). W stylu budowanych przez Halla organów widać wpływy angielskiego budownictwa organowego tego okresu (Ogasapian, "Hall" 238). Jego największe organy zostały wybudowane ok. 1820 r. dla katedry w Baltimore. Były to 35-głosowe organy (3M/P). Warto zwrócić uwagę, że w pedale na cztery głosy zastosował jeden głos 32 '. Dyspozycja organów nie podaje stopażu oprócz głosów w pedale i była następująca (Ochse 145-146):

$\begin{array}{lll}\text { Great } & \text { Swell } & \text { Choir } \\ \text { Double Open Diapason } & \text { Double Stopped Diapason } & \text { Open Diapason } \\ \text { Open Diapason } & \text { Open Diapason } & \text { Dulceano } \\ \text { Stopped Diapason } & \text { Stopped Diapason } & \text { Viol di Gamba } \\ \text { German Flute } & \text { Dulceano } & \text { Stopped Diapason } \\ \text { Night Horn } & \text { Principal } & \text { Principal } \\ \text { Principal } & \text { Fifteenth } & \text { Flute } \\ \text { Twelfth } & \text { Cornet, 4 ranks } & \text { Fifteenth } \\ \text { Fifteenth } & \text { Trumpet } & \text { Vox Humana } \\ \text { Tierce } & \text { Hautboy } & \\ \text { Sesquialtra, 4 ranks } & \text { Trimland } & \\ \text { Mixture, } 3 \text { ranks } & & \\ \text { Cornet, 5 ranks } & & \\ \text { Trumpet } & & \\ \text { Clarion, or Octave Trumpet } & & \\ \text { Pedal } & & \\ \text { Sub-bass 32' } & & \\ \text { Double Open Diapason 16' } & & \\ \text { Double Stopped Diapason 16' } & & \\ \text { Open Diapason 8' } & & \end{array}$

\subsection{Thomas Robjohn (1809-1874)}

Przy omawianiu działalności organmistrzowskiej Halla w Nowym Jorku należy wspomnieć również budowniczego organów Thomasa Robjohna, który początkowo był związany z działalnością firmy Firth \& Hall. Współpracował także ze swoim bratem Williamem oraz Williamem Pye, nowojorskim piszczałkarzem. Od 1862 r. aż do śmierci pracował w firmie Odel (Ochse 149-50). Wybudował około 15 instrumentów, między innymi w Nowym Jorku dla: St. John's Chapel (1840), Rutgers St. Presbyterian Church (1845) i South Dutch Reformed Church (1859-1862). Uważany jest za pierwszego z budowniczych 
organów, który wprowadził pneumatyczną trakturę klawiatury, także jemu, choć niesłusznie, przypisuje się wynalezienie wklęsło-radialnej klawiatury pedałowej. Jego instrumenty wyróżniały się rzeźbionymi prospektami (Pinel, „Robjohn” 468).

\subsection{Henry Erben (1800-1884)}

Drugim obok T. Halla ważnym nowojorskim organmistrzem był Henry Erben. Urodził się w Nowym Jorku w 1800 r. Jego ojciec Peter Erben był organistą kościoła św. Trójcy w Nowym Jorku. Przypuszcza się, że towarzyszył Hallowi wraz ze swoim ojcem przy instalowaniu organów w St. John Chapel w Nowym Jorku w 1813 r. Początkowo był praktykantem w warsztacie Halla, a następnie jego wspólnikiem w firmie Hall \& Erben. Od 1827 r. prowadził samodzielnie firmę aż do śmierci, czyli do roku 1884. Warto wspomnieć, że po rozwiązaniu spółki Hall \& Erben, Hall w dalszym ciągu pracował dla Erbena. Jego instrumenty były budowane głównie dla Nowego Jorku. Około 1849 r. Erben założył fabrykę w Baltimore, która działała do 1863 r. Godne odnotowania instrumenty wybudowane przez Erbena to w katedrze św. Patryka w Nowym Jorku (1868), Christ Church, Mobile, Alabama (1859), I Second Presbyterian Church, Philadelphia (1838) (Owen, „Erben” 323).

W omawianym okresie jednym z instrumentów Erbena były 32-głosowe organy $(3 \mathrm{M} / \mathrm{P})$ w Filadelfii wybudowane w 1837 r. dla Christ Church. Dyspozycję ułożył J. C. B. Standbridge, będący organistą w tym kościele, i była ona następująca (Ochse 158-59):

\section{Great Organ}

Double Stopped Diapason Large Open Diapason

2nd Open Diapason

Stopped Diapason

Principal

Nighthorn

Twelfth

Fifteenth

Seventeenth

Sesquialtra 4x $\left(G-b^{2}\right)$

Mounted Cornet 5x (C-f $\left.\mathrm{f}^{2}\right)$

Trumpet

Clarion

\section{Choir Organ}

Dulciana Open Diapason ${ }^{14}$

Stopped

Diapason

Principal

Flute

Fifteenth

Cremona
Swell Organ

Open Diapason

Viol da Gamba

Stopped Diapason

Principal

Flute

Fifteenth

Cornet, $3 \mathrm{x}$

Trumpet

Oboe

\footnotetext{
${ }^{14} 11$ piszczałek w zakresie od $\mathrm{g}^{2}-\mathrm{f}^{3}$ wykorzystuje się ze Stopped Diapason.
} 
Pedal

Double Open Diapason

Open Diapason

Principal

Połączenia: Great/Pedal, Great/Choir, Great/Swell

\subsection{George Jardine (1801-1896)}

Urodził się w Dartford w Anglii w 1801 r. ${ }^{15}$ Sztuki organmistrzowskiej uczył się w firmie Flight \& Robson w Anglii. W 1837 r. wyjechał do Nowego Jorku. Zaczynał od budowania i sprzedawania katarynek (barrel organ), ale z uwagi na mały rynek zbytu powrócił do budowy organów. Już rok po przybyciu do Nowego Jorku przyznano mu złoty medal przez American Institute za budowanie organów. W 1860 r. założył wraz ze swoim synem Edwardem G. (zm. 1896 r.) firmę Jardine \& Son. W tym okresie Jardine przeszedł w budowie organów od angielskiego XVIII-wiecznego stylu do stylu romantycznego. Było to spowodowane tym, że Edward G. Jardine, podróżując po Europie, zapoznał się z organami budowanymi między innymi przez Cavaille-Colla (Owen, „Jardine” 556).

Jardine podobnie jak Erben budował organy dla Nowego Jorku. Jak wynika z katalogu firmy do 1869 r. zostało wybudowanych 370 instrumentów. Z instrumentów wybudowanych w latach 1837-1869 należy wymienić 33-głosowe organy (3M/P) z 1858 r. w Katedrze Niepokalanego Poczęcia NMP w Mobile (Ochse 161-63).

\subsection{Richard Montgomery Ferris (1818-1857)}

Urodził się w 1818 r. w Nowym Jorku. Rozpoczął naukę, jako praktykant w warsztacie H. Erbena, gdzie miał możliwość uczenia się od samego Halla. W 1836 r. odszedł z firmy i w 1841 r. rozpoczął samodzielną działalność. Współpracował z Henrym Leamanem oraz w latach 1844-1849 z Williamem H. Davisem (Pinel, „Ferris” 194-95). Od roku 1849 aż do śmierci w 1857 r. pracował samodzielnie. Rok przed śmiercią w 1856 r. założył spółkę ze swoim bratem przyrodnim Levim U. Stuartem (Kassel, "Stuart" 543-44). Ferris wybudował około sześćdziesięciu instrumentów. Najbardziej znany jest z organów wybudowanych dla Calvary Episcopal, New York City w 1847 r. przebudowanych przez L. U. Stuarta w 1866 r. a następnie przeniesionych przez G. Beach do Roaund Lake Auditorium i odnowionych przez firmę Andover w 1977 r. (Pinel, „Ferris” 194-95 i „Beach” 58). Organy były 32-głosowe (3M/P), zakres manuału (dla głosu $8^{\prime}$ ) wynosił GG-f ${ }^{3}$ (59 klawiszy), a dla pedału (dla

\footnotetext{
${ }^{15}$ Podawany jest również rok 1800 .
} 
głosu 16') - GG-c (18 klawiszy). Pierwotna dyspozycja instrumentu z 1847 r. przedstawiała się następująco (Ochse 164-65):

Great Organ

First Open Diapason

Second Open Diapason

Stopped Diapason

First Principal

Second Principal

Night Horn (tc)

Twelfth

Fifteenth

Sesquialtera

Mixture

Trumpet

Clarion

Choir Organ

Open Diapason (G)

Dulciana

Stopped Diapason

Principal

Flute

Picolo

(tc)

Furniture (G)

Cremona
Swell Organ

Bourdon

$16^{\prime}$

Open Diapason

Dulciana

Stopped Diapason

Principal

Sesquialtera

Cornet

Trumpet

Hautboy

Clarion

$8^{\prime}$

81

$8^{\prime}$

$4^{\prime}$

III

II

$8^{\prime}$

$8^{\prime}$

$\begin{array}{lll}\text { III } & \text { Hautboy } & 8^{\prime} \\ \text { III } & \text { Clarion } & 4^{\prime}\end{array}$

$8^{\prime}$

$8^{\prime}$

Pedal Organ

Twenty-four foot stop $\quad 16^{\prime}$

Twelve-foot stop $8^{\prime}$

Połączenia: Great/Swell, Great/Choir, Choir/Swell, Pedals/Great, Pedals/Choir, Great/Swell 8va.

\subsection{Rodzina Pilcherów i Kilgenów}

Wśród budowniczych, których początki są związane z Nowym Jorkiem należy wymienić dwie rodziny organmistrzowskie: Pilcherów i Kilgenów. Henry Pilcher (1798-1880) swoją działalność organmistrzowską rozpoczynał w Anglii, gdzie w 1820 r. założył warsztat w Dover. W 1832 r. wraz z rodziną wyjechał do Stanów Zjednoczonych. Zakład organmistrzowski prowadził między innymi w Nowym Jorku w latach 1832, 1844-1847 oraz w Newark w latach 1833-1838 i 1848-1856. Wybudował 13 instrumentów, największy z nich z 1850 r. dla First Presbyterian w Newark. W 1858 r. przeszedł na emeryturę, a prowadzeniem firmy zajęli się jego synowie: Henry Jr. (1828-1890) i William (1830-1912) (Schmitt, „Pilcher” 411).

Tradycje budownictwa organowego rodziny Kilgenów sięgają XVII w., kiedy to Sebastian Kilgen miał uczyć się sztuki organmistrzowskiej w klasztorze 
położonym niedaleko Durlach (Ochse 167). W latach czterdziestych XIX w. George Kilgen (1821-1902) z przyczyn politycznych wyemigrował do Stanów Zjednoczonych, gdzie początkowo pracował dla Jardine'a, a następnie w $1851 \mathrm{r}$. założył własny warsztat organmistrzowski, który w roku 1873 przeniósł do St. Louis i prowadził ze swoim synem Charlesem (1859-1932). Kilgen budował małe mechaniczne, dwumanuałowe instrumenty, średnio 10-głosowe (2M/P). Zarówno firmy Pilcher i Kilgen rynek zbytu dla swoich organów znaleźli na Środkowym Zachodzie (Kassel, „Kilgen” 289-90).

\section{PENSYLWANIA}

Kolejnym ważnym ośrodkiem budownictwa organowego w Stanach Zjednoczonych w pierwszej połowie XIX w. była Pensylwania. Tutaj zaznaczyły swoją obecność dwie tradycje w budowie organów: niemiecka, koncentrująca się na terenach wiejskich Pensylwanii (rodziny Krauss i Dieffenbach) oraz angielska obejmująca duże miasta takie jak Philadelphia i Pittsburg (H. J. Corrie, J. C. B. Standbridge).

\subsection{Rodzina Krauss}

Firma organowa Krauss działała w okresie 1812-1905 r. Lata jej świetności przypadają na I połowę XIX w., kiedy firmą kierował Andrew Krauss, a następnie dwaj jego synowie, Joel i George. Po śmierci George'a prowadzaniem zakładu zajął się jego syn Edwin. Rodzina Kraussów specjalizowała się w budowie małych organów. $Z$ zachowanych instrumentów godne odnotowania są organy dla Old Norriton Presbyterian Church wybudowane w 1850 r. W prospekcie umieszczono 31 piszczałek, w tym 15 grających. Klawiatura pedałowa była niewielkich rozmiarów: klawisze diatoniczne miały ok. $15 \mathrm{~cm}$, a chromatyczne 6 cm. Dyspozycja instrumentu jest następująca (Ochse 176):

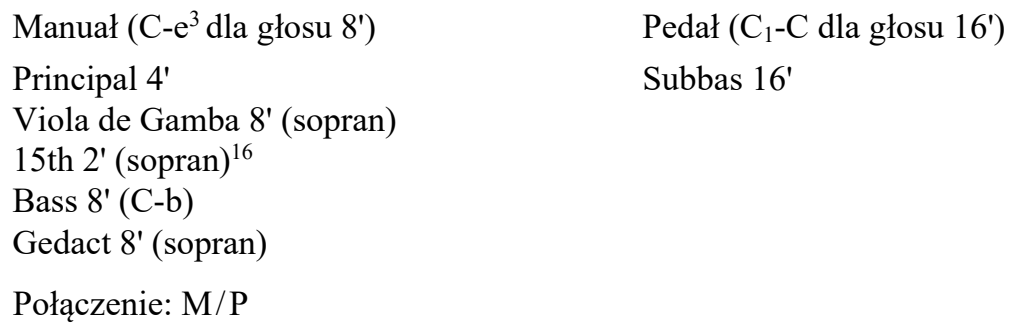

\footnotetext{
${ }^{16}$ „15th” to skrót w pisowni na oznaczenie superoktawy 2'.
} 


\subsection{Rodzina Dieffenbachów}

Drugim ważnym budowniczym w Pensylwanii była rodzina Dieffenbachów, których działalność obejmuje II poł. XVIII w. i XIX w. Założycielem tej rodzinnej firmy był John Jacob Dieffenbach (1744-1803), a kontynuatorem jego syn Christian (1769-1829) oraz wnuk David (1798-1872) i prawnuk Thomas (1821-1900). Zajmowali się budowaniem instrumentów zwykle jednomanuałowych, bez pedału, przeznaczonych dla małych kościołów. Cechą charakterystyczną budowanych przez Johna i Christiana instrumentów były dobrze wykonane prospekty z ozdobnymi piszczałkami prospektowymi (mogłoby to wskazywać na wzorowanie się na prospektach D. Tannenberga). Zachowany prospekt organów z Rehrersburg jest neobarokowy, pięciosekcyjny, trzywieżowy, z dekoracją snycerską (Lawrance, „Dieffenbach” 145).

\subsection{Henry John Corrie (1786-1858)}

Urodził się w Londynie i tam też uczył się u Thomasa Elliota, jednego z ważnych londyńskich organmistrzów. W 1822 r. wyjechał do Bostonu, aby instalować organy Elliota w South Church. Od tego czasu pozostał w Stanach Zjednoczonych i początkowo pracował dla Thomasa Appletona w latach 1823-1827 w Bostonie. W 1828 r. osiedlił się w Filadelfii i tam prowadził swój warsztat wspólnie z Johnym Huberem (1831-1837), a następnie z Williamem Wrightem. Po śmierci H. Corrie'ego zakładem kierował jego syn William ze swoim szwagrem Johnem Wrightem. Działalność syna nie ograniczała się tylko do Filadelfii, ale budował organy także w Pittsburgu, Cincinnati, Louisville, Nashville czy Baltimore. Corrie był ceniony jako dobry intonator, jego najbardziej intensywna działalność przypadła na lata 1828-1845 (Pinel, „Corrie” 126; Ochse 173).

\subsection{John C. B. Standbridge (1800-1871)}

Urodził się w Anglii. W 1807 r. jego rodzina wyemigrowała do Filadelfii. Tam ukończył szkołę medyczną. Firmę organmistrzowską założył w 1844 r. i prowadził aż do śmierci do $1871 \mathrm{r}$. Po jego śmierci firmą kierowali jego synowie George i John H. Standbridge. W 1880 r. firma została sprzedana i stała się jednym z oddziałów Roosevelt Organ Works. Z wybudowanych przez J. Standbridge organów należy wymienić czteromanuałowy instrument dla Harmonia Sacred Society Concert Hall w 1855 r. uważany wówczas za największy w Stanach Zjednoczonych. Instrumenty Standbridge były oceniane jako dobre, jeżeli chodzi o warstwę brzmieniową. Nie cieszyły się natomiast uznaniem w przypadku prospektów, które uważano za „dziwaczne” i „brzydkie” (Pinel, „Standbridge” 535; Ochse 174). 


\section{ORGANMISTRZOWIE W INNYCH STANACH}

Bez wątpienia dwa główne ośrodki budownictwa organowego koncentrowały się w Nowej Anglii i Nowym Jorku. I one oddziaływały na tereny poza nimi. Najbardziej widoczne są wpływy Henry'ego Erbena, braci Goodrich, Jamesa Halla, rodziny Pilcherów, Jardine'a, Halla \& Labagha, a także W. B. D. Simonsa. Należy podkreślić, że największe oddziaływanie zaznaczyła firma Erben. Budownictwo organowe poza Nową Anglią i Nowym Jorkiem obejmowało takie stany jak: Maryland, Południowa Karolina, Wirginia, Georgia, Luizjana, Ohio, Missouri, Illinois, Teksas, Kalifornia i Utah, a także Dystrykt Kolumbii (Waszyngton).

W stanie Maryland głównym ośrodkiem było miasto Baltimore, gdzie oprócz Erbena (który miał tam swoją fabrykę) i Jamesa Halla, działali organmistrzowie tacy jak: James Stewart, Henry F. Berger, August Pomplitz i Henry Rodewald. Na uwagę zasługuje działalność Pomplitza, który w latach 1851-1862 prowadził firmę wspólnie z Rodewaldem, a po 1862 r. kierował nią samodzielnie. Firma wybudowała około 225 instrumentów (Kassel, „United States of America” 589; Ochse 179-80; Pinel „Pomplitz” 429).

W Waszyngtonie (Dystrykt Kolumbii) działał Jacob Hilbus, organmistrz niemieckiego pochodzenia, który budował małe organy. Jeden z jego instrumentów, siedmiogłosowy pozytyw miał ciekawy zakres klawiatury od FF-f $\mathrm{f}^{3}$ i Echo dla Open Diapason 8' i Principal 4' (Ochse 180).

W Południowej Karolinie, Wirginii, Georgii, Luizjanie działali budowniczy z Nowego Jorku, a przede wszystkim Henry Erben. W 1840 r. Erben zainstalował między innymi organy w Synagodze Beth Elohim (181-82).

W stanie Ohio ważnym ośrodkiem było miasto Cincinnati, ze względu na swoje położenie. Działalność organmistrzowską prowadzili tutaj niemieccy imigranci. Wśród nich należy wymienić organmistrzów Mathiasa Schwaba i jego następcę Johanna Koehnkena oraz firmy Alfred Mathers \& Co. i Closs \& Hallenkamp. W Cleveland działał Henry Erben oraz po roku 1850 Charles Koebler, George F. Votteler. W założonym przez francuskich emigrantów mieście St. Louis (w stanie Missouri) w kościele Christ Church Episcopal (1840 r.) organy wybudował Erben. W latach 1852-1862 organy budowała firma Pilchera, a latach 1859-1861 Williama Metza. Organy budowane przez Metza, który był uważany za pierwszego stałego organmistrza w St. Louis, były małe, ale dobrej jakości. W 1859 r. otrzymał medal podczas „Mechanic's Fair”. Dobrą organmistrzowską pracę potwierdzają również organmistrzowie pracujący czy remontujący jego instrumenty (Ochse 183-88; Schmit, "Metz" 348). W Chicago 
instrumenty budował Erben, Jardine oraz Hall \& Labagh. Pierwsza lokalna firma Wolfram \& Haeckel działała w latach 1857-1867 (Ochse 188).

W stanach na południowym zachodzie należy odnotować instalację organów w Galveston (Teksas) w 1848 r. oraz 46-głosowe organy wybudowane przez Erbena w San Francisco. Z organmistrzów działających w San Francisco należy wymienić Josepha Mayera, którego zastąpiła w II połowie XIX w. firma Schoenstein (Ochse 188-89). W Salt Lake City zostały zainstalowane organy Josepha Ridgesa, organmistrza angielskiego pochodzenia, który wyemigrował do Australii, a następnie przypłynął do Stanów Zjednoczonych (Belnap, „Ridges” 465-66).

Budownictwo organowe w stanach omówionych powyżej było pod dużym wpływem budowniczych z Nowej Anglii i Nowego Jorku, a swój dynamizm uzyskało w II poł. XIX w.

\section{ZAKOŃCZENIE}

Dokonujące się w I poł. XIX w. przemiany społeczno-gospodarcze i polityczne miały znaczny wpływ na rozwój budownictwa organowego. Wśród ważnych czynników należy wymienić rozwój transportu, który napędzał wzrost gospodarczy i handel. Rewolucja w komunikacji (drogi, żegluga morska i lądowa) miała istoty wpływ na migracje ludności, osadnictwo, a co za tym idzie rozwój miast, powstawanie dużych kościołów i budowanie w nich organów. Istotnym czynnikiem był również rozwój przemysłu, który początkowo zależny od europejskiej technologii mógł pochwalić się własnymi osiągnięciami i wynalazkami. Rozkwit przemysłu przyczynił się do budowy fabryk i mechanizacji produkcji. Wymienione czynniki pociągały za sobą nie tylko powstawanie nowych firm organmistrzowskich, ale również zmianę w stylu budowy organów z tradycyjnego warsztatu na rzecz fabryk produkujących organy.

W omawianym okresie na czoło wysuwają się trzy główne ośrodki takie jak Nowa Anglia, Nowy Jork i Pensylwania. Działali organmistrzowie, spółki organmistrzowskie oraz firmy rodzinne. Za „ojca” budownictwa organowego w Nowej Anglii uważany jest William Goodrich, w którego warsztacie uczyli się między innymi bracia Hook i Stevens oraz J. H. Ware. Obok Goodricha należy wymienić Thomasa Appletona, którego instrumenty oprócz walorów brzmieniowych cieszyły się okazałymi szafami organowymi wykonanymi z drewna mahoniowego. Z budowniczych Nowej Anglii godnym odnotowania jest Joseph Alley, który budował organy pokojowe oraz do małych kościołów. 
Drugim ważnym ośrodkiem budownictwa organowego był Nowy Jork, gdzie działali organmistrzowie tacy jak: Thomas Hall, Thomas Robjohn, Henry Erben. W mniejszym zakresie działały rodziny organmistrzowskie Pilcherów i Kilgenów, które swój rynek zbytu znalazły na Środkowym Zachodzie. Trzecim nie mniej ważnym ośrodkiem budownictwa organowego była Pensylwania, gdzie działały rodziny organmistrzowskie Krauss i Dieffenbach (kontynuatorzy tradycji niemieckich) oraz organmistrzowie Henry Corrie, John Standbridge.

Budownictwo organowe $w$ innych stanach rozwijało się w mniejszym zakresie i było pod dużym wpływem budowniczych z Nowej Anglii i Nowego Jorku. Największe oddziaływanie zaznaczyła firma Erben.

Budowane instrumenty to przede wszystkim organy przeznaczone do kościołów, ale dużą popularnością cieszą się organy tzw. salonowe do użytku domowego z czasem wypierane przez fisharmonie. Wielkość budowanych organów była różna od 49 głosowych $(3 \mathrm{M} / \mathrm{P})$ do 6 głosowych $(\mathrm{M} / \mathrm{P})$. W dyspozycji instrumentów przeważały głosy $8^{\prime}$ i 4' z małą obsadą głosów w sekcji pedału, od 1-3 do 7 głosów. Częstą praktyką było stosowanie transmisji oraz głosów dzielonych, niektóre głosy zaczynały się od drugiej oktawy od c.

W omawianym okresie w Stanach Zjednoczonych organy były budowane głównie według wzorów angielskich i niemieckich. Amerykańscy organmistrzowie zaczęli także kształtować własny styl budowy organów, który będzie się rozwijał w II połowie XIX w., a zwłaszcza na początku XX w.

\section{BIBLIOGRAFIA}

Belnap, Parley. „Ridges, Joseph H(arris) (B. 1827)”. Bush, Kassel, ss. 465-466.

Bishop, Jim. „Hook (and Hook; Hook and Hastings)”. Bush, Kassel, ss. 258-259.

Bush, Douglas, i Richard Kassel, redaktorzy. The Organ: An Encyclopedia. Wyd. 2, Routledge, 2015.

Encyklopedia Historii Stanów Zjednoczonych Ameryki Pótnocnej, red. A. Bartnicki i in., Egross Morex, 1992.

Fesperman, John T. „Chamber Organ”. Bush, Kassel, ss. 106-107.

Jones, Maldwyn A. Historia USA. Narody i cywilizacje. Wydawnictwo Marabut, 2002.

Kassel, Richard. „United States of America”. Bush, Kassel, ss. 583-598.

Kassel, Richard. „Warren”. Bush, Kassel, s. 619.

Kassel, Richard. „Stuart”. Bush, Kassel, ss. 543-544.

Kassel, Richard. „Kilgen”. Bush, Kassel, ss. 289-290.

Lawrance, Arthur. „Dieffenbach”. Bush, Kassel, s. 145.

Ochse, Orpha. The History of the Organs in the United States. Indiana UP, 1988. 
Ogasapian, John K. „Hall, Thomas S. (1794-1874)”. Bush, Kassel, s. 238.

Owen, Barbara. „Alley, Joseph (1804-1880)”. Bush, Kassel, ss. 24-25.

Owen, Barbara. „Appleton, Thomas (1785-1872)”. Bush, Kassel, ss. 31-32.

Owen, Barbara. „Appleton Thomas”. Sadie, t. 1, ss. 509-510.

Owen, Barbara. „Erben Henry”. Sadie, t. 6, ss. 323.

Owen, Barbara. „Goodrich, William Marcellus”. Sadie, t. 7, ss. 531.

Owen, Barbara. „Goodrich, William M(arcellus) (1777-1833)”. Bush, Kassel, ss. 226-227.

Owen, Barbara. „Hook \& Hastings”. Sadie, t. 8, ss. 664-665.

Owen, Barbara. „Jardine George”. Sadie, t. 9, ss. 556.

Owen, Barbara. „Johnson, William Allen”. Sadie, t. 9, ss. 684.

Owen, Barbara. „Simmons, William Benjamin Dearborn”. Sadie, t. 17, ss. 323.

Paterson, Donald. „Johnson”. Bush, Kassel, ss. 281-282.

Pinel, Stephen L. „Beach, Giles (1826-1906)”. Bush, Kassel, s. 58.

Pinel, Stephen L. „Corrie, Henry (1786-1858)”. Bush, Kassel, s.126.

Pinel, Stephen L. „Ferris, Richard M(ontgomery) (1818-1858)”. Bush, Kassel, ss. 194-195.

Pinel, Stephen L. „Lowe, John (ca. 1760-1813)”. Bush, Kassel, s. 311.

Pinel, Stephen L. „Robjohn, Thomas (1809-1874)”. Bush, Kassel, s. 468.

Sadie, Stanley, redaktor. The New Grove Dictionary of Music and Musicians. Wyd. 1, Oxford UP, 1980. 20 tomów.

Schmitt, Elizabeth Towne. „Metz, William (1818-1896)”. Bush, Kassel, s. 348.

Schmitt, Elizabeth Towne. „Pilcher”. Bush, Kassel, ss. 411.

\section{GLÓWNI PRZEDSTAWICIELE BUDOWNICTWA ORGANOWEGO W STANACH ZJEDNOCZONYCH W LATACH 1815-1860}

\section{Streszczenie}

W niniejszym artykule została omówiona działalność głównych przedstawicieli budownictwa organowego w Stanach Zjednoczonych w latach 1815-1860. Był to czas przemian w stylu budownictwa organowego z tradycyjnego warsztatu na rzecz fabryk produkujących organów. Działali pojedynczy organmistrzowie, jak również rodziny i firmy organmistrzowskie. Rolę wiodącą pełniły trzy ośrodki: Nowa Anglia, Nowy Jork i Pensylwania. Czołowi organmistrzowie tych ośrodków to: bracia Goodrich, T. Appleton, T. Hall, H. Erben oraz rodziny Krauss i Dieffenbach. W innych stanach budownictwo rozwijało się w mniejszym zakresie ale było pod wpływem budowniczych z wymienionych wyżej ośrodków. Budowane instrumenty były przede wszystkim przeznaczone do kościołów ale dużą popularnością cieszyły się organy tzw. salonowe do użytku domowego (Alley and Pool) z czasem zastępowane przez fisharmonie. Początkowo organy były budowane według wzorców angielskich i niemieckich ale zaczynał się kształtować rodzimy styl budowy organów.

Słowa kluczowe: budownictwo organowe; XIX wiek; organy; organmistrzowie; rodziny organmistrzowskie; Stany Zjednoczone. 


\title{
THE MAIN REPRESENTATIVES OF ORGAN BUILDING \\ IN THE UNITED STATES IN 1815-1860
}

\begin{abstract}
S u m m a r y
In this article, the activity of the main representatives of organ building in the United States in 1815-1860 is discussed. This was a time when organ building moved from traditional organ workshops to organ factories. There were both individual organ builders and organ-building families and firms. Three centres - New England, New York and Pennsylvania - were in the lead. The main organ builders of those particular centres were: the Goodrich Brothers, Thomas Appleton, Thomas Hall and Henry Erben, as well as the Krauss and Dieffenbach families. In the other states, the building of organs was developing to a smaller extent, but it was under the influence of organ builders from the above-mentioned centres. Most organs were designated for churches, but chamber organs for home usage (Alley and Pool) were popular as well. In time, they were replaced by reed organs. Initially, organs were built according to English and German patterns, but a domestic style of organ building also started to take shape.
\end{abstract}

Keywords: organ building; 19th century; organ; organ builders; organ families, United States. 